\title{
PENERAPAN AKTIVITAS QUICK ON THE DRAW \\ MELALUI PENDEKATAN THINKING ALOUD PAIR PROBLEM SOLVING UNTUK MENINGKATKAN KEMAMPUAN KOMUNIKASI DAN PENALARAN MATEMATIS SISWA MA
}

\author{
${ }^{1)}$ Tina Rosyana, ${ }^{2)}$ Indah Puspita Sari \\ ${ }^{1)}$ tinarosyana@gmail.com, ${ }^{2)}$ chiva.aulia@ gmail.com \\ ${ }^{1,2)}$ Program Studi Pendidikan Matematika, STKIP Siliwangi
}

\begin{abstract}
ABSTRAK
Penelitian ini bertujuan untuk menelaah pencapaian dan peningkatan kemampuan komunikasi dan penalaran matematis siswa yang menggunakan aktivitas quick on the draw melalui pendekatan Thinking Aloud Problem Solving (TAPPS) dibandingkan dengan yang menggunakan pembelajaran biasa. Metode yang digunakan dalam penelitian ini yaitu metode eksperimen, dengan desain kelompok kontrol pretespostes. Populasi pada penelitian ini adalah seluruh siswa MA Negeri di Kota Cimahi, sedangkan sampel penelitiannya adalah sebanyak dua kelas dari kelas XII yang dipilih secara acak dari seluruh kelas XII yang ada. Kemudian kedua kelas tersebut dipilih menjadi kelas eksperimen dan kelas kontrol. Kelas eksperimen memperoleh aktivitas quick on the draw melalui pendekatan TAPPS dan kelas control memperoleh pembelajaran biasa. Instrumen yang digunakan dalam penelitian ini berupa soal tes kemampuan komunikasi dan penalaran matematis. Data hasil penelitian dianalisis secara kuantitatif dengan menggunakan uji statistik (uji-t). Kesimpulan yang diperoleh sebagai berikut: 1) Kemampuan komunikasi matematis siswa yang memperoleh pembelajaran dengan aktivitas quick on the draw melalui pendekatan TAPPS lebih baik daripada yang memperoleh pembelajaran biasa; 2) Kemampuan penalaran matematis siswa yang memperoleh pembelajaran dengan aktivitas quick on the draw melalui pendekatan TAPPS secara signifikan lebih baik daripada yang memperoleh pembelajaran biasa; 3) Peningkatan kemampuan komunikasi matematis siswa yang memperoleh pembelajaran dengan aktivitas quick on the draw melalui pendekatan TAPPS lebih baik daripada yang memperoleh pembelajaran biasa; dan 4) Peningkatan kemampuan penalaran matematis siswa yang memperoleh pembelajaran dengan aktivitas quick on the draw melalui pendekatan TAPPS lebih baik daripada yang memperoleh pembelajaran biasa.
\end{abstract}

Kata Kunci: Komunikasi Matematis, Penalaran Matematis, Aktivitas Quick on The Draw, Pendekatan Thinking Aloud Pair Problem Solving (TAPPS)

\begin{abstract}
This study aims to examine the achievements and improvement students' mathematical communication and mathematical reasoning ability between those who acquire learning through quick on the draw activity with TAPPS learning approach and conventional learning. The method was used in this study is the experimental method, with pretest-posttest control group design. The population was the entire students of MA Negeri in Cimahi, while the sample is two classes of grade XII selected randomly from all the existing class of grade XII. Then these two classes were randomly assigned into experimental class and control class. Experimental class gets quick on the draw activity with TAPPS learning approach and control class gets conventional learning. Research instruments include tests of mathematical communication and mathematical reasoning ability. The data were analyzed using t-test and the MannWhitney test. The results showed that (1) Students' achievement of mathematical communication ability of mathematical learning through quick on the draw activity with TAPPS learning approach is better than through conventional learning; (2) Students' achievement of mathematical reasoning ability of mathematical learning through quick on the draw activity with TAPPS learning approach is better than through conventional learning; (3) Students' improvement of mathematical communication ability of mathematical learning through quick on the draw activity with TAPPS learning approach is better than through conventional learning; (4) Students' improvement of mathematical reasoning ability of mathematical learning through quick on the draw activity with TAPPS learning approach is better than through conventional learning.
\end{abstract}


Keywords: Mathematical Communication, Mathematical Reasoning, Quick on The Draw Activity, Thinking Aloud Pair Problem Solving (TAPPS) Learning Approach.

\section{A. PENDAHULUAN}

Matematika merupakan salah satu ilmu pengetahuan yang memegang peranan penting dalam kehidupan manusia. Dalam kehidupan sehari-hari, matematika selalu dapat kita temui mulai dari matematika yang sederhana hingga yang kompleks. Matematika sebagai ilmu pengetahuan yang diperoleh dari bernalar adalah suatu ilmu dasar dan salah satu disiplin ilmu yang sangat besar pengaruhnya terhadap kemajuan dan perkembangan ilmu pengetahuan. Menurut Sujono (2001:8), matematika perlu diajarkan di sekolah karena matematika menyiapkan siswa menjadi pemikir dan penemu, matematika menyiapkan siswa menjadi warga negara yang hemat, cermat, dan efisien dan matematika membantu siswa membangun karakternya. Oleh karena itu, matematika sudah diajarkan mulai dari tingkat sekolah dasar, karena peranannya yang sangat penting dalam menghasilkan sumber daya manusia yang berkarakter.

Pentingnya pembelajaran matematika sebagai bagian dari proses pendidikan juga diperkuat oleh Badan Standar Nasional pendidikan (BSNP). BSNP (2006:345) menyatakan bahwa mata pelajaran matematika perlu diberikan kepada semua peserta didik mulai dari sekolah dasar untuk membekali peserta didik dengan kemampuan berpikir logis, analitis, sistematis, kritis, dan kreatif, serta kemampuan bekerjasama. Sejalan pula dengan kurikulum 2004 (Depdiknas, 2003), bahwa siswa setelah pembelajaran harus memiliki seperangkat kompetensi matematika yang harus ditunjukkan pada hasil belajarnya dalam pembelajaran matematika (standar kompetensi), yaitu:

$\begin{array}{llr}\text { Menunjukkan pemahaman } & \text { konsep } \\ \text { matematika } & \text { yang } & \text { dipelajari, }\end{array}$ menjelaskan keterkaitan antar konsep dan algoritma, secara luwes, akurat, efisiensi, dan tepat dalam memecahkan masalah,

2. Memiliki kemampuan mengkomunikasikan gagasan dengan simbol, tabel, grafik atau diagram untuk memperjelas keadaan atau masalah,

3. Menggunakan penalaran pada pola, sifat atau melakukan manipulasi matematika dalam membuat generalisasi, menyusun bukti, atau menjelaskan gagasan dan pernyataan matematika,

4. Menunjukkan kemampuan strategic dalam membuat (merumuskan), menafsirkan, dan menyelesaikan model matematika dalam pemecahan masalah,

5. Memiliki sikap menghargai matematika dalam kehidupan.

Dari uraian di atas, maka perlu diupayakan adanya suatu aktivitas pembelajaran yang dapat meningkatkan kemampuan komunikasi dan penalaran matematis siswa. Salah satu upaya yang dapat dilakukan adalah dengan menerapkan kegiatan pembelajaran yang dapat mendorong siswa mengkonstruksi pengetahuannya sendiri melalui kegiatan bernalar serta meningkatkan komunikasi. Salah satu cara yang diduga dapat meningkatkan kemampuan komunikasi dan penalaran matematik siswa adalah dengan menerapkan aktivitas dan strategi pembelajaran yang tepat.

Salah satunya aktivitas pembelajarannya yaitu quick on the draw melalui pendekatan Thinking Aloud Problem Solving (TAPPS). Pendekatan TAPPS dilakukan dalam kelompok kecil yang heterogen. Hal ini memungkinkan terjadinya interaksi yang positif antar siswa. Salah satu siswa berperan sebagai problem solver yang memecahkan masalah dan menyampaikan semua gagasan dan pemikirannya pasangannya, sedangkan siswa lain yang merupakan pasangannya berperan sebagai listener yang mengikuti dan mengoreksi dengan cara mendengarkan seluruh proses problem solver. Setelah menyelesaikan masalah, kemudian bertukar peran sehingga semua siswa memperoleh kesempatan menjadi problem solver dan listener.

Oleh karena itu, dengan penerapan aktivitas quick on the draw melalui pendekatan TAPPS diharapkan dapat meningkatkan kemampuan komunikasi dan penalaran matematis siswa.

Berdasarkan latar belakang masalah yang telah diuraikan sebelumnya, maka rumusan masalah dalam penelitian ini diuraikan sebagai berikut:

1. Apakah kemampuan komunikasi matematis siswa MA yang pembelajarannya menggunakan aktivitas quick on the draw melalui pendekatan TAPPS lebih baik daripada yang menggunakan pembelajaran biasa? 
2. Apakah kemampuan penalaran matematis siswa MA yang pembelajarannya menggunakan aktivitas quick on the draw melalui pendekatan TAPPS lebih baik daripada yang menggunakan pembelajaran biasa?

3. Apakah peningkatan kemampuan komunikasi matematis siswa MA yang pembelajarannya menggunakan aktivitas quick on the draw melalui pendekatan TAPPS lebih baik daripada yang menggunakan pembelajaran biasa?

4. Apakah peningkatan kemampuan penalaran matematis siswa MA yang pembelajarannya menggunakan aktivitas quick on the draw melalui pendekatan TAPPS lebih baik daripada yang menggunakan pembelajaran biasa?

Penelitian ini diharapkan bermanfaat, salah satunya yaitu dapat memberikan gambaran dan informasi mengenai aktivitas quick on the draw dan pendekatan TAPPS, sehingga dapat dijadikan bahan rujukan dan mengembangkannya dalam pembelajaran matematika.

Kemampuan komunikasi matematis siswa yang ditelaah dalam penelitian ini ialah kemampuan menulis apa yang diketahui dan apa yang ditanyakan, menjelaskan ide matematis, menulis strategi penyelesaian, membuat model atau ekspresi matematis untuk pemecahan masalah. Indikator yang digunakan yaitu menyatakan suatu situasi dengan gambar dan model matematika, menjelaskan ide, situasi, dan relasi matematika secara tertulis.

Dalam penelitian ini kemampuan penalaran yang ditelaah adalah penalaran deduktif, yaitu penarikan kesimpulan berdasarkan aturan yang disepakati. Nilai kebenaran dalam penalaran deduktif bersifat mutlak benar atau salah dan tidak keduanya bersama-sama. Indikator yang digunakan yaitu melaksanakan perhitungan berdasarkan aturan atau rumus tertentu, memberikan penjelasan terhadap model, fakta, sifat-sifat, hubungan atau pola, 3) memperkirakan jawaban dan proses solusi, mengajukan lawan contoh

\section{B. KAJIAN TEORI DAN METODE}

\section{Kajian Teori}

\section{a. Kemampuan Komunikasi Matematis}

Komunikasi merupakan alat untuk menyampaikan ide, gagasan dan pendapat baik secara lisan maupun tulisan. Pengertian komunikasi menurut Effendi (Rohaeti, 2008:10) adalah proses penyampaian suatu pesan oleh seseorang pada orang lain untuk memberi tahu atau mengubah sikap, pendapat, atau perilaku baik langsung secara lisan, maupun tidak langsung melalui media.

NCTM (Saragih, 2007) mengatakan bahwa komunikasi matematik adalah kemampuan:

1) Membaca dan menulis matematika serta menafsirkan makna dan ide dari tulisan itu,

2) Mengungkapkan dan menjelaskan pemikiran mereka tentang ide matematika dan hubungannya,

3) Merumuskan definisi matematika dan membuat generalisasi yang ditemui melalui investigasi,

4) Menulis sajian matematika dengan pengertian,

5) Menggunakan kosakata/bahasa, notasi struktur secara matematika untuk menyajikan ide, menggambarkan hubungan dan pembuatan model,

6) Memahami, menafsirkan dan menilai ide yng disajikan secara lisan, dalam tulisan atau dalam bentuk visual,

7) Mengamati dan membuat dugaan, merumuskan pertanyaan, mengumpulkan dan menilai informasi, dan menghasilkan dan menyajikan argument yang meyakinkan.

Sumarmo (2006) mengidentifikasi indikator komunikasi matematis yang meliputi kemampuan:

a) Menghubungkan benda nyata, gambar, dan diagram ke dalam ide matematika,

b) Menjelaskan ide, situasi dan relasi matematik, secara lisan dan tulisan dengan benda nyata, gambar, grafik dan aljabar,

c) Menyatakan peristiwa sehari-hari dalam bahasa atau simbol matematika,

d) Mendengarkan, berdiskusi dan menulis tentang matematika,

e) Membaca dengan pemahaman suatu presentasi matematika,

f) Menyusun konjektur, menyusun argument, merumuskan definisi dan generalisasi,

g) Mengungkapkan kembali suatu uraian atau paragraf matematika dalam bahasa sendiri.

Selanjutnya Djumhur (Mulyadiana, 2000) menyebutkan indikator untuk kemampuan komunikasi matematik secara lisan, yaitu:

(1) Indikator komunikasi lisan dalam representasi

(a) Siswa dapat menyajikan suatu penyelesaian dari suatu masalah

(b) Siswa dapat memilih cara yang paling tepat untuk menyajikan jawaban dari suatu masalah 
(c) Siswa dapat menggunakan tabel, gambar, model, dll untuk menyampaikan jawaban dari suatu masalah

(d) Memberikan saran atau pendapat lain untuk menjawab suatu permasalahan yang lebih mudah

(e) Merespon suatu pernyataan atau suatu persoalan dari audiens dalam bentuk argument yang meyakinkan

(f) Mampu mengintrepetasi dan mengevaluasi ide-ide, symbol, istilah serta informasi matematika

(g) Mengungkapkan lambing notasi dan persamaan matematika secara tepat.

(2) Indikator komunikasi lisan dalam diskusi

(a) Siswa ikut menyampaikan pendapat tentang masalah yang sedang dibahas

(b) Siswa berpartisipasi aktif dalam menanggapi pendapat yang diberikan oleh siswa lain

(c) Siswa mau mengajukan pertanyaan ketika ada sesuatu yang tidak dimengerti

(d) Siswa dapat mendengarkan secara serius ketika siswa lain mengemukakan pendapat.

Adapun yang akan menjadi indikator kemampuan komunikasi matematis dalam penelitian ini adalah kemampuan siswa untuk menyatakan hubungan benda nyata, gambar dan diagram ke dalam ide matematika; menjelaskan ide, situasi, dan relasi matematik secara tulisan dengan benda nyata, gambar, grafik dan aljabar; menyatakan peristiwa sehari-hari dalam bahasa dan simbol matematika.

\section{b. Kemampuan Penalaran Matematis}

Penalaran matematis merupakan salah satu kemampuan yang diharapkan untuk dimiliki siswa dalam mempelajari matematika (NCTM, 2000). Penalaran merupakan suatu kegiatan berpikir untuk menarik suatu kesimpulan. Menurut Shufer dan Pierce (Dahlan, 2004), istilah penalaran sebagai terjemahan dari Reasoning yang didefinisikan sebagai proses pencapaian kesimpulan logis berdasarkan fakta dan sumber yang relevan. Menurut Galloti (Maesaroh, 2007) penalaran adalah cara transformasi informasi yang diberikan dalam urutan tertentu yang menjangkau kesimpulan. Kesimpulan yang bersifat umum dapat ditarik dari kasus-kasus yang bersifat khusus, ataupun sebaliknya, dari hal yang bersifat umum menjadi kasus yang bersifat khusus.
Menurut Sumarmo (2013:6), secara garis besar penalaran matematik digolongkan dalam dua jenis yaitu penalaran induktif dan penalaran deduktif. Penalaran induktif adalah penarikan kesimpulan berdasarkan data yang teramati. Nilai kebenaran dalam penalaran induktif dapat bersifat benar atau salah. Beberapa jenis penalaran induktif yaitu:

1. Transduktif: penerapan kasus atau sifat khusus yang satu pada kasus khusus lainnya.

2. Analogi: penarikan kesimpulan berdasarkan keserupaan data atau proses.

3. Generalisasi: penarikan kesimpulan umum berdasarkan sejumlah data yang teramati.

4. Memperkirakan jawaban, solusi atau kecenderungan; interpolasi dan ekstrapolasi.

5. Memberi penjelasan terhadap model, fakta, sifat, hubungan, atau pola yang ada.

6. Menggunakan pola hubungan, menganalisa dan mensintesa beberapa kasus, dan menyusun konjektur.

Indikator penalaran menurut Sumarmo (2007) yaitu: 1) menarik kesimpulan logis; 2) memberikan penjelasan terhadap model, fakta, sifat-sifat, hubungan atau pola; 3) memperkirakan jawaban dan proses solusi; 4) menggunakan pola hubungan untuk menganalisis situasi, atau membuat analogi, generalisasi dan menyusun konjektur; 5) mengajukan lawan contoh; 6) mengikuti aturan inferensi, memeriksa validitas argument, membuktikan dan menyusun argument yang valid; dan 7) menyusun pembuktian langsung, tak langsung, dan pembuktian dengan induksi matematika.

\section{c. Aktivitas Quick on The Draw}

Quick on the draw merupakan sebuah aktivitas riset untuk kerja tim dan kecepatan. Tujuannya adalah menjadi kelompok pertama yang menyelesaikan satu set pertanyaan. Kegiatan pembelajaran dengan aktivitas quick on the draw di dalamnya dapat membantu siswa untuk membiasakan diri belajar pada sumber, bukan guru dan sesuai dengan siswa yang memiliki karakteristik tidak dapat duduk diam selama lebih dari dua menit. Quick on the draw akan memberikan pengalaman mengenai macam-macam keterampilan membaca, yang didorong oleh kecepatan aktivitas, ditambah belajar mandiri dan kecakapan ujian yang lain, membaca pertanyaan dengan hati-hati, menjawab pertanyaan dengan tepat, serta membedakan materi yang penting dan yang tidak (Ginnis, 2002:146-147). 
Ginnis (2008:163) mengungkapkan bahwa terdapat 9 langkah aktivitas quick on the draw, yaitu sebagai berikut:

1. Siapkan satu set pertanyaan, misalnya sepuluh, mengenai topik yang akan dibahas. Tiap kelompok memiliki satu set pertanyaan sendiri dan setiap pertanyaan harus di kartu terpisah. Tiap set pertanyaan sebaiknya di kartu dengan warna yang berbeda. Letakkan set pertanyaan tersebut di atas meja guru, angka menghadap ke atas dan angka nomor 1 diletakkan paling atas,

2. Bagi KE dalam kelompok-kelompok kecil. Beri warna untuk tiap kelompok, sehingga mereka dapat mengenali set pertanyaan mereka di meja guru,

3. Tiap siswa dalam tiap kelompok diberi materi sumber yang terdiri dari jawaban untuk semua pertanyaan, bisa berupa halaman tertentu dari buku teks yang biasanya. Jawaban sebaiknya tidak begitu jelas agar siswa berinisiatif untuk mencari jawaban lengkapnya di buku teks,

4. Pada kata "mulai", satu orang (orang pertama) dari tiap kelompok berjalan ke meja guru, mengambil pertanyaan pertama menurut warna mereka dan kembali membawanya ke kelompok,

5. Kelompok tersebut berdiskusi mencari jawaban pertanyaan dan kemudian jawaban ditulis di lembar kertas terpisah,

6. Setelah selesai, jawaban diberikan kepada guru oleh orang kedua. Guru memeriksa jawaban. Jika jawaban akurat dan lengkap, pertanyaan kedua dari tumpukan warna mereka dapat diambil. Begitu seterusnya. Jika ada jawaban yang tidak akurat atau tidak lengkap, guru menyuruh siswa tersebut kembali ke kelompok dan mencoba lagi. Siswa yang menulis, mengambil pertanyaan, dan mengembalikan jawaban harus bergantian,

7. Saat satu siswa sedang mengembalikan jawaban, siswa yang lain menandai sumbernya dan membiasakan diri dengan isinya, sehingga mereka dapat menjawab pertanyaan selanjutnya dengan lebih efisien,

8. Kelompok yang menang adalah yang pertama menjawab semua pertanyaan,

9. Guru bersama siswa menjawab semua pertanyaan dan siswa membuat catatan tertulis.

\section{d. Pendekatan Thinking Aloud Pair Problem Solving (TAPPS)}

Dalam bahasa Indonesia Thinking Aloud artinya berfikir keras, Pair artinya berpasangan dan
Problem Solving artinya penyelesaian masalah. Jadi Thinking Aloud Pair Problem Solving (TAPS) dapat diartikan sebagai aktivitas berfikir keras secara berpasangan dalam menyelesaikan masalah. Pendekatan TAPPS ini lebih menekankan pada penyelesaian masalah. Pendekatan ini pertama kali diperkenalkan oleh Claparade, yang kemudian digunakan oleh Bloom dan Bloder untuk meneliti proses pemecahan masalah pada mahasiswa perguruan tinggi. Selanjutnya pendekatan ini dikembangkan oleh Lochhead dan Whimbey untuk meningkatkan kemampuan penyelesaian masalah siswa.

Berikut merupakan perincian langkah-langkah pemecahan masalah yang dilakukan oleh problem solver dan listener yang dikemukakan Stice (1987),

1. Dibentuk kelompok yang terdiri dari dua atau tiga orang siswa yang berperan sebagai problem solver dan listener. Kemudian diberikan permasalahan,

2. Problem solver mengemukakan semua pendapat serta gagasan yang terpikirkan kemudian mengungkapkannya dengan katakata. Mengemukakan semua langkah yang dilakukan sebelum mulai menyelesaikan suatu masalah,

3. Listener membantu problem solver melihat apa yang harus dikerjakan. Hal ini berarti seorang listener harus membuat agar problem solver mengungkapkan apa yang problem solver lakukan,

4. Listener ikut berpikir bersama problem solver, mengikuti setiap langkah dan mengerti setiap langkah tersebut. Jika tidak mengerti, maka bertanya kepada problem solver,

5. Listener mengikuti dan memeriksa langkah penyelesaian masalah yang diambil problem solver dengan cara memeriksa langkah atau perhitungan yang dilakukan oleh problem solver, jika listener menemukan kesalahan yang dibuat oleh problem solver, hindarkan untuk mengoreksi, bantu problem solver memecahkan masalah dengan cara memberikan pertanyaan penuntun yang mengarah ke jawaban yang benar,

6. Setelah problem solver dapat memecahkan masalah, maka siswa bertukar posisi antara yang bertugas sebagai problem solver dan listener untuk menyelesaikan permasalahan lain,

7. Langkah 2 sampai 6 terus berulang sampai semua permasalahan dapat diselesaikan. 
2. Metode

Metode yang digunakan dalam penelitian ini adalah metode eksperimen, dengan desain kelompok kontrol pretes-postes. Pada jenis desain eksperimen ini terjadi pengelompokan subjek secara acak kelas, adanya pretes dan postes. Kelas eksperimen yaitu kelas yang mendapatkan pembelajaran dengan aktivitas quick on the draw melalui pendekatan Thinking Aloud Pair Problem Solving (TAPPS). Kelas kontrol yaitu kelas yang mendapatkan pembelajaran biasa.

Desain penelitiannya (Ruseffendi, 2010:50) berbentuk:
A
O $\quad \mathrm{X} \quad \mathrm{O}$
A
$\mathrm{O} \quad \mathrm{O}$

Keterangan:

A : Sampel penelitian dipilih secara acak kelas.

$\mathrm{O} \quad$ : Pretes $=$ postes (tes kemampuan komunikasi dan penalaran matematis).

$\mathrm{X}$ : Perlakuan pembelajaran dengan aktivitas quick on the draw melalui pendekatan TAPPS.

Populasi pada penelitian ini adalah seluruh siswa di salah satu MA Negeri di Kota Cimahi semester ganjil Tahun Ajaran 2015/2016. Sampel yang diambil dalam penelitian ini adalah siswa kelas XI. Dari beberapa kelas XI, kemudian dipilih secara acak kelas dua kelas sebagai kelas eksperimen dan kelas kontrol. Instrumen yang digunakan adalah instrumen tes berbentuk uraian untuk mengukur kemampuan komunikasi dan penalaran matematis siswa.

\section{HASIL DAN PEMBAHASAN}

\section{Hasil}

Pada bagian ini disajikan data hasil penelitian serta analisis menggunakan uji statistik. Data deskriptif hasil penelitian sebelum dan sesudah pembelajaran disajikan dalam tabel rekapitulasi berikut ini.

Tabel 1. Rekapitulasi Hasil Pretes, Postes, dan Gain Kemampuan Komunikasi dan Penalaran Matematis

\begin{tabular}{|c|c|c|c|c|}
\hline \multirow[b]{3}{*}{ Kelas } & \multirow[b]{3}{*}{ Tes } & \multirow[b]{3}{*}{ Stat. } & \multirow{2}{*}{\multicolumn{2}{|c|}{ Aspek Kemampuan }} \\
\hline & & & & \\
\hline & & & $\begin{array}{c}\text { Komunikasi } \\
\text { Matematis }\end{array}$ & $\begin{array}{l}\text { Penalaran } \\
\text { Matematis }\end{array}$ \\
\hline \multirow{3}{*}{$\begin{array}{l}\text { Eksperimen } \\
\text { (KE) }\end{array}$} & \multirow[b]{2}{*}{ Pretes } & $\overline{\mathrm{x}}$ & 2,78 & 0,19 \\
\hline & & s & 1,18 & 0,46 \\
\hline & Postes & $\overline{\mathrm{x}}$ & 15,35 & 13,89 \\
\hline
\end{tabular}


Tabel 2. Hasil Uji Perbedaan Rataan Data Pretes Kemampuan Komunikasi dan Penalaran Matematis

\begin{tabular}{lclc}
\hline Aspek & Mann- & Asymp.Sig. & $\mathrm{H}_{0}$ \\
& $\begin{array}{c}\text { Whitney- } \\
\text { (2-tailed })\end{array}$ & \\
\hline $\begin{array}{l}\text { Komunikasi } \\
\text { Matematis }\end{array}$ & 556,000 & 0,284 & Terima \\
$\begin{array}{l}\text { Penalaran } \\
\text { Matematis }\end{array}$ & 644,500 & 0,958 & Terima \\
\hline
\end{tabular}

Hipotesis yang diuji untuk kemampuan awal komunikasi matematis yaitu:

$\mathrm{H}_{0}$ : Tidak terdapat perbedaan kemampuan awal komunikasi matematis siswa yang memperoleh KE dan KK.

$\mathrm{H}_{1}$ : Terdapat perbedaan kemampuan awal komunikasi matematis siswa yang memperoleh KE dan KK.

Kriteria pengujian, jika nilai probabilitas (Sig.) lebih dari 0,05, maka $\mathrm{H}_{0}$ diterima. Dari Tabel 2, dapat dilihat bahwa hipotesis nol diterima. Artinya tidak terdapat perbedaan kemampuan awal komunikasi matematis $\mathrm{KE}$ dengan $\mathrm{KK}$.

Hipotesis yang diuji untuk kemampuan penalaran matematis adalah $\mathrm{H}_{0}$ : Tidak terdapat perbedaan kemampuan awal penalaran matematis siswa yang memperoleh $\mathrm{KE}$ dan $\mathrm{KK} . \mathrm{H}_{1}$ : Terdapat perbedaan kemampuan awal penalaran matematis siswa yang memperoleh KE dan KK.

Dari Tabel 2, dapat dilihat bahwa hipotesis nol diterima. Artinya tidak terdapat perbedaan kemampuan awal penalaran matematis KE dengan KK. Jadi, dapat ditarik kesimpulan bahwa sebelum pembelajaran dilakukan siswa kedua kelas (KE dan KK) memiliki kemampuan yang sama pada aspek kemampuan komunikasi maupun penalaran matematis.

\section{Analisis Data Postes Kemampuan Komunikasi dan Penalaran Matematis}

Analisis data postes dilakukan dengan penghitungan uji perbedaan dua rata-rata data postes kemampuan komunikasi dan penalaran matematis KE dan KK menggunakan uji non parametrik Mann Whitney.
Tabel 3. Hasil Uji Perbedaan Rataan Postes Kemampuan Komunikasi Matematis

\begin{tabular}{lccc}
\hline & $\begin{array}{c}\text { Mann- } \\
\text { Whitney- } \\
\mathrm{U}\end{array}$ & $\begin{array}{c}\text { Asymp.Sig. } \\
(\text { l-tailed })\end{array}$ & $\mathrm{H}_{0}$ \\
\hline $\begin{array}{l}\text { Komunikasi } \\
\text { Matematis }\end{array}$ & 140,000 & 0,000 & Tolak \\
\hline
\end{tabular}

Hipotesis yang diuji untuk kemampuan komunikasi matematis yaitu:

$\mathrm{H}_{0}$ : kemampuan komunikasi matematis siswa KE tidak lebih baik atau sama dengan KK.

$\mathrm{H}_{1}$ : kemampuan komunikasi matematis siswa KE lebih baik daripada KK.

Kriteria pengujian, jika nilai probabilitas (Sig.) lebih dari 0,05 , maka $\mathrm{H}_{0}$ diterima. Berdasarkan Tabel 3, hipotesis nol ditolak, sehingga hipotesis kedua atau hipotesis alternatif $\left(\mathrm{H}_{1}\right)$ diterima. Dengan demikian dapat disimpulkan bahwa kemampuan komunikasi matematis siswa yang memperoleh pembelajaran dengan aktivitas quick on the draw melalui pendekatan thinking aloud pair problem solving lebih baik daripada yang memperoleh pembelajaran biasa.

Tabel 4. Hasil Uji Perbedaan Rataan Postes Kemampuan Penalaran Matematis

\begin{tabular}{lccc}
\hline & $\begin{array}{c}\text { Mann- } \\
\text { Whitney- } \\
\mathrm{U}\end{array}$ & $\begin{array}{c}\text { Asymp.Sig. } \\
(\text { 1-tailed })\end{array}$ & $\mathrm{H}_{0}$ \\
\hline $\begin{array}{l}\text { Penalaran } \\
\text { Matematis }\end{array}$ & 11,000 & 0,000 & Tolak \\
\hline
\end{tabular}

Untuk kemampuan penalaran matematis, hipotesis yang diujinya yaitu:

$\mathrm{H}_{0}$ : kemampuan penalaran matematis siswa KE tidak lebih baik atau sama dengan KK.

$\mathrm{H}_{1}$ : kemampuan penalaran matematis siswa KE lebih baik daripada KK.

Kriteria pengujian, jika nilai probabilitas (Sig.) lebih dari 0,05 , maka $\mathrm{H}_{0}$ diterima.

Berdasarkan kriteria pengujian, dapat dilihat pada Tabel 3 bahwa hipotesis nol ditolak, sehingga hipotesis kedua atau hipotesis alternatif $\left(\mathrm{H}_{1}\right)$ diterima. Oleh karena itu dapat disimpulkan bahwa kemampuan penalaran matematis siswa yang memperoleh pembelajaran dengan aktivitas quick on the draw melalui pendekatan thinking aloud pair problem solving lebih baik daripada yang memperoleh pembelajaran biasa. 


\section{Analisis Peningkatan Kemampuan Komunikasi dan Penalaran Matematis}

Untuk menganalisis peningkatan kemampuan komunikasi dan penalaran matematis dilakukan uji perbedaan rataan $\mathrm{N}$-Gain $\mathrm{KE}$ dan $\mathrm{KK}$ dengan menggunakan uji non-parametrik Mann-Whitney

Tabel 5. Hasil Uji Perbedaan Rataan Peningkatan Kemampuan Komunikasi Matematis

\begin{tabular}{lc}
\hline \multicolumn{2}{c}{ Kemampuan Komunikasi Matematis } \\
\hline Mann-Whitney-U & 126,000 \\
Asymp.Sig.(1-tailed) & 0,000 \\
$\mathrm{H}_{0}$ & Tolak \\
\hline
\end{tabular}

Hipotesis peningkatan kemampuan komunikasi matematis yang diujikan yaitu:

$\mathrm{H}_{0} \quad$ : peningkatan kemampuan komunikasi matematis siswa KE tidak lebih baik atau sama dengan KK.

$\mathrm{H}_{1} \quad$ : peningkatan kemampuan komunikasi matematis siswa KE lebih baik daripada KK.

Kriteria pengujian, jika nilai probabilitas (Sig.) lebih dari 0,05 , maka $\mathrm{H}_{0}$ diterima.

Pada Tabel 5 di atas terlihat hipotesis nol ditolak karena nilai sig. yang kurang dari 0,05 . Oleh karena itu hipotesis alternatif $\left(\mathrm{H}_{1}\right)$ diterima. Dengan demikian, dapat disimpulkan bahwa peningkatan kemampuan komunikasi matematis siswa yang memperoleh pembelajaran dengan aktivitas quick on the draw melalui pendekatan TAPPS lebih baik daripada yang memperoleh pembelajaran biasa.

\begin{tabular}{lc}
\multicolumn{2}{c}{$\begin{array}{c}\text { Tabel 6. Hasil Uji Perbedaan Rataan } \\
\text { Peningkatan Kemampuan Penalaran } \\
\text { Matematis }\end{array}$} \\
\hline \multicolumn{2}{c}{ Kemampuan Penalaran Matematis } \\
\hline Mann-Whitney-U & 9,500 \\
Asymp.Sig.(1-tailed) & 0,000 \\
$\mathrm{H}_{0}$ & Tolak \\
\hline
\end{tabular}

Hipotesis peningkatan kemampuan penalaran matematis yang diujikan yaitu:
$\mathrm{H}_{0}$ : peningkatan kemampuan penalaran matematis siswa KE tidak lebih baik atau sama dengan $\mathrm{KK}$.

$\mathrm{H}_{1}$ : peningkatan kemampuan penalaran matematis siswa KE lebih baik daripada KK.

Kriteria pengujian, jika nilai probabilitas (Sig.) lebih dari 0,05 , maka $\mathrm{H}_{0}$ diterima.

Pada Tabel 6 hipotesis nol ditolak, sehingga hipotesis alternatif $\left(\mathrm{H}_{1}\right)$ diterima. Dengan demikian, dapat disimpulkan bahwa peningkatan kemampuan penalaram matematis siswa yang memperoleh pembelajaran dengan aktivitas quick on the draw melalui pendekatan TAPPS lebih baik daripada yang memperoleh pembelajaran biasa.

\section{Pembahasan}

Pembahasan hasil penelitian ini didasarkan pada faktor-faktor yang dicermati dalam penelitian ini.Faktor-faktor tersebut meliputi pembelajaran dengan aktivitas quick on the draw melalui penedekatn TAPPS, peningkatan kemampuan komunikasi dan penalaran matematis.

\section{a. Pembelajaran dengan Aktivitas Quick on the Draw melalui Pendekatan TAPPS}

Berdasarkan analisis terhadap data hasil penelitian diperoleh bahwa siswa yang memperoleh pembelajaran dengan aktivitas quick on the draw melalui pendekatan TAPPS, peningkatan kemampuan komunikasi dan penalaran matematisnya lebih baik dibandingkan dengan siswa yang memperoleh pembelajaran biasa. Aktivitas quick on the draw melalui pendekatan TAPPS berpengaruh terhadap kemampuan komunikasi dan penalaran matematis.

Secara umum pelaksanaan pembelajaran dengan aktivitas quick on the draw melalui pendekatan TAPPS telah berjalan sesuai dengan yang diharapkan. Beberapa hal yang peneliti temukan dalam pelaksanaan penelitian mengenai pembelajaran dengan aktivitas quick on the draw melalui pendekatan TAPPS antara lain:

1. Sebelum memulai penelitian, terlebih dahulu peneliti dan guru matematika berdiskusi dan melakukan tinjauan pada pembelajaran yang telah dan akan dilakukan. Selanjutnya, peneliti memberi pengarahan-pengarahan kepada siswa tentang pembelajaran yang akan dilakukan sesuai dengan skenario yang telah disusun. Pada kesempatan ini peneliti juga 
menyampaikan pokok bahasan yang akan diteliti.

2. Pada pertemuan pertama, peneliti mengawali kegiatan pembelajaran dengan menyampaikan tujuan pembelajaran, memberikan apersepsi dan motivasi terutama menjelaskan manfaat materi yang dipelajari pada kehidupan sehari-hari. Kemudian peneliti menyampaikan pentingnya memiliki kemampuan komunikasi dan penalaran matematis. Selanjutnya peneliti membagi kelompok siswa dimana setiap kelompok terdiri dari 2 atau 3 orang yang akan berperan sebagai problem solver dan listener dengan kemampuan yang heterogen. Siswa diberikan penjelasan mengenai tugas problem solver dan listener. Kemudian peneliti membagikan LKS kepada setiap kelompok.

3. Aktivitas quick on the draw melalui pendekatan TAPPS ini merupakan pembelajaran yang baru bagi siswa, sehingga pada pertemuan pertama dan kedua siswa masih belum terbiasa mengikuti setiap langkah pada kegiatan pendahuluan.

4. Pada kegiatan inti, semua kelompok diberikan pengarahan mengenai materi yang akan dipelajari, kemudian guru meminta semua kelompok untuk bersama-sama menelaah soal yang diberikan, kemudian menyelesaikan permasalahan yang diberikan pada LKS maupun pada kartu. Masing-masing siswa diminta merencanakan penyelesaian dari permasalahan yang diberikan. Siswa yang berperan sebagai problem solver bertugas memberikan penjelasan setiap langkah yang dilakukan selama penyelesaian masalah kepada listener. Siswa yang berperan sebagai listener bertugas untuk mendengarkan dan memperhatikan setiap langkah yang dikerjakan oleh problem solver dalam memecahkan masalah. Jika ada hal yang tidak dipahami, maka listener dapat mengajukan pertanyaan kepada problem solver. Jika ada kesalahan pengerjaan yang ditemukan oleh problem solver, maka listener dapat memberikan pertanyaan penuntun kepada problem solver, tetapi listener jangan memberikan jawaban yang tepat.

5. Selanjutnya, setelah kegiatan mengerjakan LKS atau kartu selesai, maka guru memberikan kesempatan kepada perwakilan kelompok untuk menyelesaikan tugasnya secara berlombalomba, dan bersiap untuk menyajikan hasil diskusi kelompok di depan kelas. Siswa menyajikan hasil diskusi kelompoknya di depan kelas, sedangkan siswa yang lain memberikan tanggapan dan masukan agar jawaban atas permasalahan yang diberikan pada LKS atau kartu menjadi lebih tepat. Guru memandu jalannya diskusi siswa. Kemudian siswa bersama guru membahas hasil diskusi kelompok dengan menunjukan jawaban yang tepat. Siswa diberikan kesempatan untuk menanyakan, menjelaskan atau menyimpulkan hal-hal yang belum dipahami/diketahui.

6. Kemudian peneliti membimbing dan mengarahkan siswa untuk membuat rangkuman akhir hasil kegiatan diskusi dan bersama guru menyusun kesimpulan yang tepat. Pada kegiatan penutup tersebut, siswa dan guru melakukan kegiatan refleksi untuk melihat kelebihan dan kekurangan dalam prses pembelajaran, setelah itu siswa diberikan pekerjaan rumah (PR).

7. Setelah pembelajaran selesai, siswa terlihat lebih bersemangat ketika kelompok mereka menjawab pertanyaan dan memberikan pendapat dengan tepat. Beberapa siswa yang pada pembelajaran biasa hampir tidak pernah aktif dan lebih banyak diam tampak aktif dalam kelompoknya.

Untuk mengetahui hasil belajar siswa dari dua kelas yang menjadi sampel penelitian, maka diberikan pretes dan postes.Pretes diberikan sebelum pembelajaran bertujuan untuk memperoleh temuan tentang kemampuan awal komunikasi dan penalaran matematis siswa berkenaan dengan materi yang diberikan. Hasil pretes secara umum menunjukkan bahwa para siswa dari kedua kelas (KE dan KK) mempunyai kemampuan yang relatif sama pada aspek kemampuan komunikasi dan penalaran matematis. Ini dapat dilihat pada analisis hasil pretes kemampuan komunikasi dan penalaran matematis pada Tabel 1.

Setelah pelaksanaan pembelajaran yang berbeda selesai, maka pada KE dan KK dilaksanakan postes. Postes yang diberikan bertujuan untuk mengetahui perolehan hasil belajar siswa setelah proses pembelajaran. Hasil rata-rata postes berdasarkan pembelajaran yang dipilih dapat dilihat pada pada Tabel 1 .

\section{b. Analisis Peningkatan Kemampuan Komunikasi dan Penalaran Matematis}

Berdasarkan data N-gain kemampuan komunikasi matematis siswa, diperoleh bahwa rataan $\mathrm{N}$-gain KK adalah 0,39 berarti termasuk dalam kategori 
sedang dan rataan $\mathrm{N}$-gain $\mathrm{KE}$ adalah 0,74 berarti termasuk dalam ketegori tinggi. Selisih rataan gain kemampuan komunikasi matematis antara KE dan KK adalah sebesar 0,35. Selanjutnya, melalui uji statistik diperoleh kesimpulan bahwa peningkatan kemampuan komunikasi matematis siswa yang memperoleh pembelajaran dengan TAPPS lebih baik daripada siswa yang memperoleh pembelajaran biasa.

Selanjutnya, data hasil peningkatan kemampuan penalaran matematis dideskripsikan dan dianalisis. Kemampuan awal penalaran matematis siswa KK dan KE diperoleh dari hasil pretes dan dapat dilihat bahwa rataan pretes $\mathrm{KK}$ adalah 0,17 dengan simpangan baku 0,38, sedangkan untuk rataan pretes KE adalah 0,19 dengan simpangan baku 0,46. Jika dilihat rataan kemampuan awal KE lebih tinggi dibandingkan dengan $\mathrm{KK}$, perbedaannya rataannya sebesar 0,02 . Namun secara statistik rataan pretes tersebut menunjukkan bahwa tidak terdapat perbedaan secara signifikan antara kemampuan awal siswa KE dengan KK.

Berdasarkan data N-gain untuk kemampuan penalaran matematis siswa, diperoleh bahwa rataan $\mathrm{N}$-gain $\mathrm{KK}$ adalah 0,26 berarti termasuk dalam kategori rendah dan rataan $\mathrm{N}$-gain $\mathrm{KE}$ adalah 0,69 berarti termasuk dalam ketegori sedang. Selisih rataan gain penalaran matematis antara KE dan KK adalah sebesar 0,43. Selanjutnya, melalui uji statistik diperoleh kesimpulan bahwa peningkatan kemampuan penalaran matematis siswa KE lebih baik daripada siswa yang memperoleh pembelajaran biasa.

\section{KESIMPULAN}

Dari hasil penelitian ini diperoleh kesimpulan sebagai berikut:

1. Kemampuan komunikasi matematis siswa yang memperoleh pembelajaran dengan aktivitas quick on the draw melalui pendekatan TAPPS lebih baik daripada yang memperoleh pembelajaran biasa.

2. Kemampuan penalaran matematis siswa yang memperoleh pembelajaran dengan aktivitas quick on the draw melalui pendekatan TAPPS secara signifikan lebih baik daripada yang memperoleh pembelajaran biasa.

3. Peningkatan kemampuan komunikasi matematis siswa yang memperoleh pembelajaran dengan aktivitas quick on the draw melalui pendekatan TAPPS lebih baik daripada yang memperoleh pembelajaran biasa.

4. Peningkatan kemampuan penalaran matematis siswa yang memperoleh pembelajaran dengan aktivitas quick on the draw melalui pendekatan TAPPS lebih baik daripada yang memperoleh pembelajaran biasa

Berdasarkan kesimpulan di atas, maka peneliti mengemukakan beberapa saran sebagai berikut:

a. Bagi guru matematika, pembelajaran dengan aktivitas quick on the draw melalui pendekatan TAPPS sebaiknya digunakan sebagai salah satu alternatif pendekatan pembelajaran untuk diimplementasikan dalam pengembangan pembelajaran matematika di kelas, terutama untuk meningkatkan kemampuan komunikasi dan penalaran matematis siswa.

b. Pembelajaran matematika dengan aktivitas quick on the draw melalui pendekatan TAPPS sebaiknya dapat diterapkan dalam jangka waktu yang lebih lama, dengan tujuan agar proses pembelajaran menjadi lebih optimal.

c. Untuk menerapkan pembelajaran dengan aktivitas quick on the draw melalui pendekatan TAPPS, sebaiknya guru membuat sebuah skenario dan perencanaan yang lebih baik, sehingga pembelajaran dapat berjalan secara sistematis sesuai dengan rencana, dan diharapkan guru menyediakan benda nyata atau model yang sesuai dengan pokok bahasan yang diajarkan.

d. Perlu dilakukan penelitian lanjutan, tetapi pada level sekolah tinggi atau rendah atau terhadap jenjang pendidikan lainnya seperti SD/MI, SMA sederajat, dan perguruan tinggi.

\section{E. DAFTAR PUSTAKA}

Badan Standar Nasional Pendidikan (BSNP). (2006). Panduan Penyusunan Kurikulum Tingkat Satuan Pendidikan Jenjang Pendidikan Dasar dan Menengah. Jakarta: BSNP.

Dahlan, J. A. (2004). Meningkatkan Kemampuan Penalaran dan Pemahaman Matematik Siswa Sekolah Lanjutan Tingkat Pertama melalui Pendekatan Open-Ended. Disertasi UPI: Tidak diterbitkan.

Depdiknas. (2003). Kurikulum 2004 Standar Kompetensi Mata Pelajaran Matematika Sekolah Menengah Atas (SMA) dan Madrasah Aliyah (MA). Jakarta: Depdiknas.

Ginnis, P. (2002). The Teacher's Toolkit: Raise Classroom Achievement with Strategies for 
Every Learner. United Kingdom: Crown House Publishing Limited.

Ginnis, P. (2008). Trik dan Taktik Mengajar. Jakarta: Indeks

Maesarah, S. (2007). Meningkatkan Kemampuan Penalaran Matematik Siswa Sekolah Menengah Atas melalui Pembelajaran Penemuan Terbimbing dengan Menggunakan Tugas Bentuk Superitem. Tesis UPI Bandung: Tidak diterbitkan.

Mulyadiana, T. S. (2000). Kemampuan Berkomunikasi Siswa Madrasah Aliyah melalui Pembelajaran Kooperatif pada Konsep Sistem Reproduksi Manusia. Tesis UPI Bandung: Tidak diterbitkan.

NCTM. (2000). Principles and Standards for School Mathematics. Reston, VA: NCTM. [Online].Tersedia:http://www.nctm.org/standa rs/overview.htm. [Mei 2015].

Rohaeti E, E. (2008). Pembelajaran Matematika dengan Menggunakan Metode IMPROVE untuk Meningkatkan Kemampuan Pemahaman dan Kemampuan Komunikasi Matematika siswa SLTP. Disertasi pada Sekolah Pascasarjana UPI: Diterbitkan pada Educationist, tahun 2010.

Saragih, S. (2007). Mengembangkan Kemampuan Berpikir Logis dan Komunikasi Matematik Siswa SMP melalui Pendekatan Realistik. Disertasi pada Sekolah Pasca Sarjana UPI: Tidak diterbitkan.

Stice, J. E. (1987). Teaching Problem Solving. [Online]. Tersedia: http://wwwcsi.unian.it/educa/problemsolvin g/stice_ps.html.[3 Februari2015].

Sudjono (2001). Pembelajaran Matematika untuk Sekolah Menengah. Jakarta: Departemen Pendidikan dan Kebudayaan.

Sumarmo, U. (2006). Berpikir Matematik Tingkat Tinggi: Apa, Mengapa, dan Bagaimana Dikembangkan pada Siswa Sekolah Menengah dan Mahasiswa Calon Guru. Makalah Disajikan pada Seminar Pendidikan Matematika di Jurusan Matematika FMIPA Universitas Padjadjaran Tanggal 22 April 2006: Tidak diterbitkan.

Sumarmo, U. (2013). Berpikir dan Disposisi Matematik Serta Pembelajarannya. Kumpulan Makalah. UPI. Bandung: Tidak Terbitkan. 